\title{
Corneal and intraocular penetration of topical and subconjunctival fusidic acid
}

\author{
PETER B TAYLOR, EILEEN M BURD, AND KHALID F TABBARA \\ From the Research Department, King Khaled Eye Specialist Hospital and Department of Ophthalmology, \\ King Saud University, Riyadh, Saudi Arabia
}

SUMMARY Corneal tissue absorption and intraocular penetration of fusidic acid were assessed in the rabbit after topical or subconjunctival application. Corneal tissue levels of fusidic acid one hour after the last topical application of the drug were well above the minimum inhibitory concentrations (MICs) for most Gram-positive and many Gram-negative organisms. Adequate levels were achieved in the aqueous at one hour following the last topical application, but no significant levels were detected in the vitreous. The corneal tissue and aqueous levels declined at 12 and 24 hours following the last drug application, however, corneal tissue levels at 24 hours were considered to be above the MICs for most Gram-positive organisms. A single subconjunctival injection of $100 \mathrm{mg}$ of fusidic acid produced levels above the MICs of most organisms in the cornea, aqueous, and vitreous which persisted over 24 hours, but subconjunctival injection of fusidic acid at this concentration resulted in conjunctival necrosis and corneal decompensation. Fusidic acid penetrates well into avascular tissue and fully penetrates corneas with both intact and debrided epithelium, as evidenced by the intracameral drug levels. Good corneal penetration and absence of known topical toxicity make fusidic acid suitable for the treatment of microbial keratitis caused by susceptible organisms.

Fusidic acid (Fucidin) is an antibiotic isolated from the fermentation products of the fungus Fusidium coccineum. It is chemically related to cephalosporin P1 but has no cross-reactivity with any other commonly used antibiotics. Since its introduction in 1962 fusidic acid has been used systemically for the treatment of severe staphylococcal infections and topically for skin infections. It has the greatest antistaphylococcal (both beta-lactamase positive and negative) activity of any antimicrobial agent currently available. ${ }^{1-3}$

The topical ophthalmic fusidic acid preparation (Fucithalmic) would be expected to be effective against Gram-positive organisms and many Gramnegative eye pathogens including Neisseria spp., Moraxella spp. Haemophilus aegyptius ${ }^{2+6}$ as well as Mycobacterium ${ }^{47}$ and Chlamydia. ${ }^{8}$ Fusidic acid is especially effective against staphylococci which are predominant in the aetiology of Gram-positive

Correspondence to Khalid F Tabbara, MD, King Khaled Eye Specialist Hospital, PO Box 7191, Riyadh 11462, Saudi Arabia. bacterial keratitis. Fusidic acid can penetrate avascular tissue even in large collections of pus," "1" making it an attractive antibiotic for the treatment of bacterial keratitis. The present study was designed to assess the corneal tissue, aqueous, and vitreous levels of fusidic acid following topical application or subconjunctival injection.

\section{Materials and methods}

ANIMALS AND METHODS OF TREATMENT

Forty-two New Zealand White male rabbits weighing 4 to $5 \mathrm{~kg}$ each were divided into three groups. Group A consisted of 18 rabbits in which a $5.5 \mathrm{~mm}$ diameter area of corneal epithelium was debrided in both eyes under topical anaesthesia. A Greishaber trephine was used to mark the area, and a No. 15 Bard Parker blade and $Q$ tip swabs were used to remove the epithelium. All right eyes received a loading dose of fusidic acid $1 \%$ viscous eyedrops, one drop every minute for five minutes, followed by one drop every hour for the next 10 hours. The left eyes received 
placebo (the vehicle of the viscous eyedrops without fusidic acid) and had the same dosage schedule as the right eyes. Group B consisted of 18 rabbits which were treated in the same manner as those in group $\mathrm{A}$, but the corneal epithelium was left intact. Six rabbits in each of the two groups (A and B) were killed by an overdose of pentobarbital at 1,12 , and 24 hours after receiving the last eyedrop. Group $\mathrm{C}$ consisted of six rabbits which received a subconjunctival injection in the right eye of $100 \mathrm{mg}$ of fusidic acid in $0.5 \mathrm{ml}$ of $0.9 \%$ sodium chloride at the beginning of the study. The left eye of each rabbit served as a control and was given a subconjunctival injection of $0.5 \mathrm{ml}$ of $0.9 \%$ sodium chloride. Two rabbits were killed at 1,12 , and 24 hours after the subconjunctival injection of fusidic acid.

\section{COLLECTION OF SPECIMENS}

Immediately after the rabbits were killed peripheral blood was obtained by cardiac puncture. The blood was allowed to clot and was centrifuged at $3000 \mathrm{~g}$ for 10 minutes to obtain the serum. Before the intraocular fluid samples were obtained, the globe of each animal was rinsed with $0.9 \%$ sodium chloride to remove any remaining antibiotic. Aqueous was drawn with a $30 \mathrm{G}$ needle attached to a tuberculin syringe inserted into the anterior chamber via a puncture at the limbus of each globe. Vitreous samples were obtained by inserting an $18 \mathrm{G}$ needle attached to a $3 \mathrm{ml}$ syringe into the midvitreal cavity $4 \mathrm{~mm}$ posterior to the limbus at the $7 \mathrm{o}$ 'clock position and withdrawing $1 \mathrm{ml}$ of vitreous fluid. After anterior chamber and vitreous taps the corneas were excised at the limbus leaving no scleral rim. All specimens were frozen and stored at $-80^{\circ} \mathrm{C}$ until the bioassays were performed.

\section{DETERMINATION OF FUSIDIC ACID LEVELS}

The levels of fusidic acid were determined in a masked fashion by an agar plate diffusion method with a reference preparation of diethanolamine fusidate as standard. Filter paper discs (Whatman AA, $6 \mathrm{~mm}$ diameter) were used for the standard dilutions and were compared with the serum, aqueous, and vitreous samples, which were placed on the surface of agar plates seeded with either Sarcina lutea ATCC 9341 or Corynebacterium xerosis FF as test organisms. Corneas were weighed and placed directly on to the seeded agar plates. Zones of inhibition were measured and the values were obtained by comparison with the standard dilution. The values obtained for the cornea samples were adjusted to levels per $100 \mathrm{mg}$ of tissue. Fusidic acid is highly protein-bound $(95-99 \%)$, and the results express the total amount, both free and proteinbound, of antibiotic. The sensitivity of the biological assay is $0.02 \mu \mathrm{g} / \mathrm{ml}$ of fusidic acid.
Table 1 Fusidic acid concentrations in topical fusidic acid treated and placebo treated eyes with intact corneal epithelium

\begin{tabular}{|c|c|c|c|}
\hline & & Fusidic acid & Placebo \\
\hline \multicolumn{4}{|c|}{ Cornea $(\mu \mathrm{g} / 100 \mathrm{mg})$} \\
\hline & $\begin{array}{l}\text { Range } \\
\text { Mean }+\mathrm{SD}\end{array}$ & $\begin{array}{c}6 \cdot 20-15 \cdot(00 \\
10 \cdot 57 \pm 3 \cdot 13\end{array}$ & $<0 \cdot(02$ \\
\hline $12 \mathrm{~h}$ & $\begin{array}{l}\text { Range } \\
\text { Mean +SD }\end{array}$ & $\begin{array}{l}2 \cdot 20-8 \cdot 40 \\
4 \cdot 65 \pm 2 \cdot 31\end{array}$ & $<0 \cdot(12$ \\
\hline $24 \mathrm{~h}$ & $\begin{array}{l}\text { Range } \\
\text { Mean } \pm S D\end{array}$ & $\begin{array}{l}1 \cdot 30-9 \cdot 60 \\
3 \cdot 78 \pm 3 \cdot 35\end{array}$ & $<0 \cdot 02$ \\
\hline \multicolumn{4}{|c|}{ Aqueous $(\mu \mathrm{g} / \mathrm{ml})$} \\
\hline $1 \mathrm{~h}$ & $\begin{array}{l}\text { Range } \\
\text { Mean } \pm S D\end{array}$ & $\begin{array}{l}0 \cdot 21-8 \cdot 20 \\
3 \cdot 22 \pm 2 \cdot 84\end{array}$ & $<0 \cdot 02$ \\
\hline $12 \mathrm{~h}$ & $\begin{array}{l}\text { Range } \\
\text { Mean } \pm S D\end{array}$ & $\begin{array}{r}<0.02-0.28 \\
0.17 \pm 0.24\end{array}$ & $<0 \cdot 02$ \\
\hline $24 \mathrm{~h}$ & $\begin{array}{l}\text { Range } \\
\text { Mean } \pm \text { SD }\end{array}$ & $\begin{array}{r}<0.02-1.50 \\
0.25 \pm 0.61\end{array}$ & $<0 \cdot 02$ \\
\hline \multicolumn{4}{|c|}{ Vitreous $(\mu \mathrm{g} / \mathrm{ml})$} \\
\hline $1 \mathrm{~h}$ & $\begin{array}{l}\text { Range } \\
\text { Mean } \pm S D\end{array}$ & $\begin{array}{r}<0.02-1.30 \\
0.25 \pm 0.52\end{array}$ & $<0 \cdot 02$ \\
\hline $12 \mathrm{~h}$ & $\begin{array}{l}\text { Range } \\
\text { Mean } \pm S D\end{array}$ & $\begin{array}{r}<0 \cdot 02-0 \cdot 66 \\
0 \cdot 10 \pm 0 \cdot 27\end{array}$ & $<0.02$ \\
\hline $24 \mathrm{~h}$ & $\begin{array}{l}\text { Range } \\
\text { Mean } \pm S D\end{array}$ & $<0.02$ & $<0 \cdot 02$ \\
\hline
\end{tabular}

The Wilcoxon signed rank test was used to compare the mean values of fusidic acid in each sample group.

\section{Results}

Tables 1 and 2 present the results of the microbioassay of fusidic acid levels in the cornea, aqueous, and vitreous of the fusidic acid treated and placebo treated eyes with intact or removed epithelium at 1 , 12 , and 24 hours following the last application of eyedrop. The highest levels of fusidic acid were found in the corneas one hour after treatment. At this time debrided corneas had higher fusidic acid concentrations $(63.81$ (SD 85.69) $\mu \mathrm{g} / 100 \mathrm{mg}$ ) than corneas with intact epithelium $(10.57$ (SD 3.13) $\mu \mathrm{g} / 100 \mathrm{mg}$ ), but the difference was not statistically significant $(p=0 \cdot 19)$. After 12 hours the mean fusidic acid concentration in the corneal tissue was lower for both debrided (2.55 (SD 1.48) $\mu \mathrm{g} / 100 \mathrm{mg}$ ) and animals with intact epithelium (4.65 (SD 2.31) $\mu \mathrm{g} / 100 \mathrm{mg}$ ). The fusidic acid levels present at 12 hours were maintained through 24 hours in most animals (3.78 (SD 3.35) $\mu \mathrm{g} / 100 \mathrm{mg}$ with epithelium intact and 3.50 (SD 2.84) $\mu \mathrm{g} / 100 \mathrm{mg}$ with epithelium removed) $(\mathrm{p}=$ $0 \cdot 88$ ). However, at 24 hours significant difference between treated and control eyes remained only in the epithelium intact group $(p=0 \cdot 046)$.

The aqueous humour level of fusidic acid at one hour showed no statistically significant difference $(p=0 \cdot 660)$ between the group with ablated epithelium $(2.49(\mathrm{SD} 2.70) \mu \mathrm{g} / \mathrm{ml})$ and that with intact epithelium 
Table 2 Fusidic acid concentrations in topical fusidic acid treated and placebo treated eyes with removal of corneal epithelium

\begin{tabular}{|c|c|c|c|}
\hline & & Fusidic acid & Placebo \\
\hline \multicolumn{4}{|c|}{ Cornea $(\mu \mathrm{g} / 100 \mathrm{mg})$} \\
\hline $1 \mathrm{~h}$ & $\begin{array}{l}\text { Range } \\
\text { Mean } \pm S D\end{array}$ & $\begin{array}{c}4 \cdot 50-232 \cdot(0) \\
63 \cdot 81 \pm 85 \cdot 69\end{array}$ & $<0 \cdot 02$ \\
\hline $12 \mathrm{~h}$ & $\begin{array}{l}\text { Range } \\
\text { Mean } \pm S D\end{array}$ & $\begin{array}{l}1 \cdot 50-5 \cdot 20 \\
2 \cdot 55 \pm 1 \cdot 48\end{array}$ & $<0 \cdot(12$ \\
\hline $24 \mathrm{~h}$ & $\begin{array}{l}\text { Range } \\
\text { Mean } \pm S D\end{array}$ & $\begin{array}{l}1 \cdot 20-9 \cdot(0) \\
3 \cdot 50 \pm 2 \cdot 84\end{array}$ & $<0 \cdot(12$ \\
\hline \multicolumn{4}{|c|}{ Aqueous $(\mu g / m l)$} \\
\hline & $\begin{array}{l}\text { Range } \\
\text { Mean } \pm \text { SD }\end{array}$ & $\begin{array}{l}(0 \cdot 02-7 \cdot 40 \\
2 \cdot 49 \pm 2 \cdot 70\end{array}$ & $<0 \cdot(02$ \\
\hline $12 \mathrm{~h}$ & $\begin{array}{l}\text { Range } \\
\text { Mean } \pm S D\end{array}$ & $\begin{array}{r}<0 \cdot(02-0.41 \\
0.13 \pm 0.20\end{array}$ & $<0 \cdot 02$ \\
\hline $24 \mathrm{~h}$ & $\begin{array}{l}\text { Range } \\
\text { Mean } \pm S D\end{array}$ & $<0 \cdot(02$ & $<0 \cdot 02$ \\
\hline \multicolumn{4}{|c|}{ Vitreous $(\mu \mathrm{g} / \mathrm{ml})$} \\
\hline & $\begin{array}{l}\text { Range } \\
\text { Mean } \pm S D\end{array}$ & $\begin{array}{r}<0 \cdot(02-1 \cdot 50 \\
0.25 \pm 0.61\end{array}$ & $<0 \cdot() 2$ \\
\hline $12 \mathrm{~h}$ & $\begin{array}{l}\text { Range } \\
\text { Mean } \pm S D\end{array}$ & $\begin{array}{r}<0 \cdot(02-5 \cdot 70 \\
0.95 \pm 2 \cdot 33\end{array}$ & $<0 \cdot(12$ \\
\hline $24 \mathrm{~h}$ & $\begin{array}{l}\text { Range } \\
\text { Mean } \pm S D\end{array}$ & $<0 \cdot 02$ & $<0 \cdot 02$ \\
\hline
\end{tabular}

(3.22 (SD 2.84) $\mu \mathrm{g} / \mathrm{ml})$. However, the aqueous level of fusidic acid was significantly higher than the aqueous humour levels of the placebo treated eyes $(p=0.05$ epithelium removed, $p=0.03$ epithelium intact). Minimal concentrations of fusidic acid could be detected in the aqueous of some animals at 12 and 24 hours after treatment, but these levels were not significantly higher than in the placebo-treated eyes.

The vitreous fusidic acid levels showed no statistically significant differences between the fusidic acid treated and placebo treated eyes at 1, 12, or 24 hours after treatment. Furthermore, there was no significant differences between the fusidic vitreous levels of the eyes with ablated and those with intact epithelium.

No detectable serum concentration of fusidic acid was present in any of the animals treated with topical fusidic acid.

Subconjunctival injection of $100 \mathrm{mg}$ of fusidic acid in $0.9 \%$ sodium chloride produced high ocular tissue absorption in the cornea, aqueous, and vitreous (Table 3). The subconjunctival fusidic acid, however, caused severe conjunctival necrosis and corneal oedema, noted at 12 hours following the injection.

\section{Discussion}

Fusidic acid is considered to be one of the most effective antistaphylococcal agents available. It is effective against the $\beta$-lactamase-producing, methicillin-resistant, and multiresistant strains. Fusidic acid acts by inhibiting protein synthesis by interference with the translocation step of peptide chain elongation and is bactericidal at concentrations close to the minimum inhibitory concentrations of 0.03 to $0.16 \mu \mathrm{g} / \mathrm{ml} .^{1112}$

Initially some concern arose regarding the rapidity with which some staphylococci develop resistance to fusidic acid in vitro. ${ }^{134}$ This finding, however, with rare exceptions, has not been reflected in the clinical eradication of infections ${ }^{4}{ }^{111} 13$ and transfer of resistance from fusidic acid-resistant to fusidic acid-sensitive strains has not been detected. ${ }^{13}$ Nonetheless, combined therapy with antibiotics such as penicillin, methicillin, or erythromycin has been recommended by some investigators. ${ }^{14}$ It has also been noted that the presence of corticosteroids markedly reduces the antistaphylococcal activity of fusidic acid in vitro. ${ }^{15}$

Previous studies have shown that therapeutic levels of fusidic acid were present in the aqueous and vitreous of normal and inflamed eyes as early as 24 hours after oral administration of $1500 \mathrm{mg}$ of sodium fusidate given in three daily divided doses. ${ }^{16} 17$ Intraocular penetration of fusidic acid occurs by simple diffusion across the blood-aqueous barrier and is not inhibited by carbonic anhydrase inhibitors. Owing to its ability to penetrate avascular tissue fusidic acid would also be expected to achieve high corneal concentrations when applied topically. In this study we found that topical application of $1 \%$ fusidic acid viscous eyedrops resulted in corneal tissue levels of fusidic acid well above the MICs for Staphylococcus spp., Streptococcus spp., Corynebacterium, Haemo-

Table 3 Fusidic acid concentrations following subconjunctival administration of fusidic acid

\begin{tabular}{|c|c|c|c|}
\hline & & Fusidic acid & Placebo \\
\hline \multicolumn{4}{|c|}{ Cornea $(\mu \mathrm{g} / 100 \mathrm{mg})$} \\
\hline \multirow[t]{2}{*}{$1 \mathrm{~h}$} & Range & $871-1970$ & $2 \cdot 7-14$ \\
\hline & Mean $\pm S D$ & $1330 \pm 640$ & $8 \cdot 35 \pm 7 \cdot 99$ \\
\hline \multirow[t]{2}{*}{$12 \mathrm{~h}$} & Range & $1 \cdot 0-970$ & $4 \cdot 2-14 \cdot 94$ \\
\hline & Mean $\pm S D$ & $486 \pm 674$ & $7 \cdot 49 \pm 10 \cdot 53$ \\
\hline \multirow[t]{2}{*}{$24 \mathrm{~h}$} & Range & $439-946$ & $2 \cdot 6-8 \cdot 7$ \\
\hline & Mcan $\pm S D$ & $692 \pm 358$ & $5 \cdot 6.5 \pm 4 \cdot 31$ \\
\hline \multicolumn{4}{|c|}{ Aqueous $(\mu \mathrm{g} / \mathrm{ml})$} \\
\hline \multirow[t]{2}{*}{$1 \mathrm{~h}$} & Range & $18-26$ & $<0 \cdot 02$ \\
\hline & Mcan $\pm S D$ & $22 \pm 5 \cdot 65$ & \\
\hline \multirow[t]{2}{*}{$12 \mathrm{~h}$} & Range & $15-23$ & $<0 \cdot() 2-0 \cdot 7()$ \\
\hline & Mcan $\pm S D$ & $19 \pm 5 \cdot 66$ & $(0.35 \pm(0.49$ \\
\hline \multirow[t]{2}{*}{$24 \mathrm{~h}$} & Range & $12-19$ & $<0 .(02-0) \cdot 25$ \\
\hline & Mcan $\pm S D$ & $15 \cdot 5 \pm 4 \cdot 95$ & $(0.125 \pm 0.18$ \\
\hline \multicolumn{4}{|c|}{ Vitreous $(\mu \mathrm{g} / \mathrm{ml})$} \\
\hline \multirow[t]{2}{*}{$1 \mathrm{~h}$} & Range & $3 \cdot 9-5 \cdot 2$ & $<0 \cdot() 2-0.43$ \\
\hline & Mean \pm SD & $4.55 \pm 0.92$ & $(0 \cdot 21 \pm 0 \cdot 30$ \\
\hline \multirow[t]{2}{*}{$12 \mathrm{~h}$} & Range & $9 \cdot 4-15$ & $<() \cdot(12-0) \cdot 98$ \\
\hline & Mcan $\pm S D$ & $12 \cdot 2 \pm 3 \cdot 96$ & $0.49 \pm 0.69$ \\
\hline \multirow[t]{2}{*}{$24 \mathrm{~h}$} & Range & $2 \cdot 7-21$ & $<0 \cdot(02$ \\
\hline & Mcan $\pm S D$ & $11 \cdot 8 \pm 12 \cdot 9$ & \\
\hline
\end{tabular}


Table 4 Antibacterial spectrum of fusidic acid

\begin{tabular}{|c|c|}
\hline Organism & $\begin{array}{l}\text { Minimum inhibitory } \\
\text { Concentration } \\
(\mu g / m l)\end{array}$ \\
\hline \multicolumn{2}{|l|}{ Gram-positive bacteria } \\
\hline Staphylococcus epidermidis & $0 \cdot 13$ \\
\hline $\begin{array}{l}\text { Staphylococcus aureus } \\
\quad \text { (penicillinasc-producing) }\end{array}$ & $0 \cdot 10$ \\
\hline $\begin{array}{l}\text { Staphylococcus aureus } \\
\quad \text { (non-pcnicillinase-producing) }\end{array}$ & $0 \cdot(05$ \\
\hline Streptococcus pneumoniae & $6 \cdot 8$ \\
\hline Streptococcus pyogenes & $1 \cdot()$ \\
\hline Streptococcus viridans group & 1.6 \\
\hline Streptococcus faecalis & 4.() \\
\hline Corynebacterium xerosis & $0 \cdot 016$ \\
\hline \multicolumn{2}{|l|}{ Gram-negative bacteria } \\
\hline Haemophilus influenzae & $3 \cdot 2-25$ \\
\hline Haemophilus aegyptius & $0 \cdot 20$ \\
\hline $\begin{array}{l}\text { Neisseria gonorrhoeae } \\
\quad \text { (including } \beta \text {-lactamase-producing strains) }\end{array}$ & $0 \cdot 40$ \\
\hline Neisseria meningitidis & 0.56 \\
\hline Moraxella lacunata & $0 \cdot 05$ \\
\hline Pseudomonas sp. & $>100 \cdot 00$ \\
\hline \multicolumn{2}{|l|}{ Miscellaneous } \\
\hline Chlamydia trachomatis & $4 \cdot()$ \\
\hline Mycobacterium tuberculosis & $1 \cdot()$ \\
\hline Nocardia asteroides & $2 \cdot 5$ \\
\hline \multicolumn{2}{|l|}{ Fungi } \\
\hline Candida & $>100 \cdot(00)$ \\
\hline Aspergillus & $>100 \cdot 00$ \\
\hline Trichophyton & $>100 \cdot 00$ \\
\hline
\end{tabular}

philus, Neisseria, Moraxella, Chlamydia, Mycobacterium tuberculosis, and Nocardia (Table 4).

The above concentrations were obtained in the corneas of New Zealand white rabbits one hour after a loading dose of one drop of the $1 \%$ fusidic acid given each minute for five minutes followed by one drop every hour for 10 hours. Corneal tissue penetration was higher, but was not significantly different in corneas in which the epithelium had been removed before administration of the antibiotic. Fusidic acid was found to penetrate the full thickness of the cornea as shown by the presence of significant levels of fusidic acid levels in the aqueous. The vitreous of some animals contained adequate levels of fusidic acid. This, however, was not a consistent finding, and no statistically significant difference could be found in comparison with placebo treated eyes. Serum samples failed to reveal the presence of fusidic acid in the systemic circulation following topical administration.

Although the fusidic acid had cleared the aqueous humour by 12 hours in most animals, significantly raised levels persisted for 12 hours in the corneas of the group with debrided epithelium and up to 24 hours in corneas with intact epithelium. These corneal levels were well above the mean inhibitory concentrations for Staphylococcus spp., most Strepto- coccus spp., other Gram-positive organisms, and many Gram-negative organisms (Table 4).

A single subconjunctival injection of $100 \mathrm{mg}$ produced high fusidic acid levels in the cornea, aqueous, and vitreous which persisted over 24 hours after treatment. However, severe conjunctival necrosis and corneal oedema resulted, thereby limiting the usefulness of subconjunctival administration of fusidic acid at this concentration.

The low toxicity of topical fusidic acid, along with the good corneal and intracameral penetration following topical administration established in this study, makes fusidic acid a promising therapeutic agent in the treatment of many types of bacterial keratitis, especially of staphylococcal aetiology.

We thank Robert L Phillips, PhD, and William Greer, PhD, of King Faisal Specialist Hospital and Research Centre for their help with statistical analysis of the data.

We thank Monzer Jabak, research co-ordinator, for his help in this study. We also thank Lorna Arcinue and Emily Rabe for their assistance in the preparation of this manuscript.

\section{References}

1 Barber M, Waterworth P. Antibacterial activity in vitro of fucidin. Lancet 1962; i: 931-2.

2 Newman RL. Bhat KM. Hackncy R. Robinson C. Stewart GT. Fusidic acid: laboratory and clinical assessment. Br Med J 1962; ii: $1645-7$.

3 King K, Brady LM, Harkness JL. Gentamicin-resistant staphylococci. Lancet 1981: ii: 698-9.

4 Godtfredson WO, Roholt K. Tybring L. Fucidin: a new orally active antibiotic. Lancet 1962: ii: 137-48.

4 Tabbara KF, Lawson NA, Burd EM. In vitro susceptibility to fusidic acid of clinically significant isolates from ocular infections. Saudi Med J 1987: 8: 167-70.

6 Jacobsen J. The sensitivity of eye pathogenic bacteria towards fucidin, chloramphenicol, and tetracycline given as MIC values. Bacteriological Department, Leo Pharmaceuticals Ltd, 20/5, 1980 .

7 Hilson GRF. In vitro studics of a new antibiotic (fucidin). Lancet 1962; i: 932-3.

8 Ridgway GL. Oricl JD. Activity of antimicrobials against Chlamydia trachomatis in vitro. J Antimicrob Chemother 1979; 5: 483-4.

9 Taylor G, Bloor K. Antistaphylococcal activity of fucidin. Lancet 1962; i:935-7.

10 Crosbic RB. Treatment of staphylococcal infections with fucidin. Br Med J 1963; i: 788-94.

11 Stewart GT. Steroidal antibiotics. Pharmakotherapia 1964; 1: 137-48.

12 Kucers A. Bennett JM. The use of antibiotics. 3rd ed. London: Heinemann, 1979.

13 Pattison JR. Mansell PE. Fucidin-resistant staphylococci in current hospital practice. J Med Microbiol 1973; 6: 235-44.

14 Goodwin AW, Rich GE, Tynan MJ. Fusidic acid in staphylococcal infection. Lancet 1973; ii: 1504-5.

15 Raab WP. The interaction of corticosteroids and antimicrobial agents used in topical therapy. Br J Dermatol 1971; 84: 482-9.

16 Chadwick AJ, Jackson B. Intraocular penetration of the antibiotic Fucidin. BrJ Ophthalmol 1969; 53: 26-9.

17 Williamson J, Russell F, Doig WM, Patterson RWW. Estimation of sodium fusidate levels in human serum, aqueous humour, and vitreous body. Br J Ophthalmol 1970); 54: 126-30.

Accepted for publication 10 September 1986. 